\title{
Gyrodactylus derjavini infections in four salmonids: comparative host susceptibility and site selection of parasites
}

\author{
Kurt Buchmann*, Anders Uldal \\ Department of Veterinary Microbiology, Section of Fish Diseases, Royal Veterinary and Agricultural University,
} 13 Bülowsvej, DK-1870 Frederiksberg C., Denmark

\begin{abstract}
The susceptibility of 4 salmonids [rainbow trout Oncorhynchus mykiss, brown trout Salmo trutta, a Baltic (Iijoki) and an Atlantic (Conon) strain of Salmo salar] to infection with a Danish isolate of Gyrodactylus derjavini was tested in the laboratory $\left(12\right.$ to $13^{\circ} \mathrm{C}$ ). Initial parasite attachment numbers did not differ between species, but parasite populations increased significantly faster and to a higher level in rainbow trout compared to the other salmonids, with S. trutta exhibiting an intermediate position. The 2 strains of $S$. salar became only slightly infected during the following weeks despite a heavy infection pressure. The parasites' selection of microhabitat on the hosts also differed between species and changed over time on the same host species. The tail fin was the preferred site in all salmonids although the pectoral, pelvic and anal fins were important sites in the initial period of the 6 wk investigation. It is notable that the corneal surface, especially in the Baltic salmon, became increasingly more heavily infected in the later stages of the infection period. Explanations for the differing degrees of susceptibility are suggested and some of these were investigated. Lysozyme activity in the fin epithelia and the density of mucous cells in the fins from the hosts were compared. Marked lysozyme activity was detected in tail fins from the 4 salmonids, but the activity was not associated with host resistance to infection. In contrast, the density of superficial mucous cells, which showed regional variation on the tail fins, was negatively correlated with susceptibility to infection. Thus, fish with high density of epithelial mucous cells showed the lowest susceptibility to infection, and this finding is discussed in relation to host resistance.
\end{abstract}

KEY WORDS: Monogeneans - Gyrodactylids - Rainbow trout - Brown trout - Baltic salmon - Atlantic salmon - Susceptibility - Site selection

\section{INTRODUCTION}

The host specificity of monogeneans is a characteristic feature of this animal group clearly appreciated in the literature (Bychowski 1957, Kearn 1994). Even monogeneans able to infect a range of host species show a clear predilection for certain hosts (Jahn \& Kuhn 1932, Nigrelli \& Breder 1934). Some gyrodactylids exhibit an ability to infect a range of species in certain teleost families. Gyrodactylus salaris is able to colonize a number of salmonids with varying success (Bakke 1991, Bakke et al. 1992b). However, the host factors responsible for these differences are poorly elucidated. Both chemical communication elements

•E-mail: kurt.buchmann@vetmi.kvl.dk and host immune factors have been suggested to be of importance (Kearn 1976). Serum components were early demonstrated to affect survival of the ectoparasitic monogeneans Benedenia (Epibdella) melleni in vitro (Nigrelli \& Breder 1934), and immunoglobulins, complement and lysozyme in serum were suggested by Vladimirov (1971) to affect survival of the gill parasite Dactylogyrus spp. in carp. Although a weak antibody reaction to monogenean antigens is found in fish (Buchmann 1993), other factors including cellular reactions should be considered. The mucous cell density in the tail fin of the rainbow trout has been demonstrated to decrease during the infection period with $G$. colemanensis and G. salmonis (Wells \& Cone 1990), but whether this factor is related to host specificity is unknown. Differing emission of specific chem- 
ical stimuli extensively used in fish communication (Hara 1993) could be involved as well. The present paper describes the different degrees of susceptibility of 4 salmonids to infection with $G$. derjavini and the site specificity of the monogeneans, and contributes to the elucidation of the factors which are of importance to this differential susceptibility of salmonids to infections with gyrodactylids.

\section{MATERIALS AND METHODS}

Parasites. An isolated strain of Gyrodactylus derjavini was obtained from a Danish rainbow trout farm (Paelebro Dambrug) in the southeastern part of Jutland. Infected rainbow trout (total body length 10 to $15 \mathrm{~cm}$ ) were transported to the laboratory in oxygenated water and kept as a laboratory host/parasite system in aerated $200 \mathrm{l}$ aquaria at 12 to $13^{\circ} \mathrm{C}$

Fish. Parasite-free salmonid fry (total body length 4 to $5 \mathrm{~cm}, 3$ to 4 mo post-hatching) were obtained from different Danish hatcheries using recirculated well or tap water. Brown trout Salmo trutta fry were purchased from Haraldsted Production (Zealand); rainbow trout Oncorhynchus mykiss were delivered by Siglund Fish Production (Mön); Scottish Conon Atlantic salmon Salmo salar were obtained from Brusgaard Production (Jutland); and Finnish Iijoki Baltic salmon Salmo salar were delivered by Bornholms Salmon Hatchery (Nexö, Bornholm). All fish were acclimatized for more than a week in a thermostat-regulated cold room $\left(12\right.$ to $\left.13^{\circ} \mathrm{C}\right)$, as field data suggest this temperature to be suitable for Gyrodactylus derjavini population increase (Buchmann \& Bresciani 1997). Fishes were kept in $200 \mathrm{l}$ fish tanks until infection and were fed a restricted diet of commercial pelleted feed 3 times a week.

Water and fish tanks. For all purposes local tap water was used. This water has at delivery a $\mathrm{pH}$ of 7.43 to 7.46 , a nitrate content of less than $10 \mathrm{mg} \mathrm{l}^{-1}$, no nitrite and ammonia, and a total hardness of 24 degrees (Merck aquacant). During population studies fishes were held in continuously aerated glass aquaria (total volume $200 \mathrm{l}$ ) containing $100 \mathrm{l}$ water. Aquarium water was recirculated by internal biofilters (Eheim) and checked regularly for $\mathrm{pH}$ and the presence of ammonia, nitrite and nitrate (Merck aquacant). Three-quarters of the water volume was exchanged twice a week.

Temperature. All experiments, including counting of parasites and infection procedures, were conducted in a thermostat-regulated cold room $\left(12\right.$ to $\left.13^{\circ} \mathrm{C}\right)$.

Light. Fish were kept under a natural light-dark cycle (14 to $16 \mathrm{~h}$ light and 8 to $10 \mathrm{~h}$ darkness).

Parasite counting. The number of Gyrodactylus derjavini were counted on anaesthetized $\left(50 \mathrm{mg} \mathrm{l}^{-1} \mathrm{MS}\right.$ 222) salmonids using a dissecting microscope with subillumination (magnification $20 \times$ to $50 \times$ ). During investigations fish were examined weekly over a $6 \mathrm{wk}$ period.

Infection procedure. Infected rainbow trout (10 to $12 \mathrm{~cm}$ body length) with a known parasite burden were killed by a blow to the head whereafter scrapings of fins, body surfaces and the rest of the carcass were placed in a plastic aquarium (volume 10 l) containing 31 water to secure that all the counted parasites were present and dispersed maximally. Such an aquarium containing a known number of monogeneans was used to infect 20 receptor fish. These were exposed to the parasites for $24 \mathrm{~h}$. Thus, 2 small aquaria were used to infect 40 fish. After this period the fishes were examined for parasites and placed in $200 \mathrm{l}$ aquaria with other fishes as described below (Table 1). Both rainbow trout and the salmonid to be tested were infected in this way for each experiment. Thus, 6 small aquaria were used to infect the rainbow trout, 2 small aquaria were used for the brown trout, 2 small aquaria were used for Scottish salmon and 2 small aquaria were used for the Baltic salmon infection procedure.

Monitoring of infection dynamics. After infection, the infected fishes were transferred to $200 \mathrm{I}$ aquaria containing a total of 80 fish (40 rainbow trout as reference and additional 40 specimens of another salmonid to be tested; Table 1).

Site specificity. The numbers of parasites on different fins and body parts according to Fig. 1 were recorded on all fish immediately after infection (Week 1) and thereafter weekly for a total of $6 \mathrm{wk}$.

Lysozyme activity in fins. Micrococcus lysodeikticus agarose plates were prepared according to Lie et al. (1986). Tail fins from uninfected fish belonging to the same batches as were used for the infection experiments (10 rainbow trout as reference and 10 fins from another salmonid species) were placed on the agarose

Table 1. Experimental groups. Each aquarium. (Aq.; 200 I) contained $100 \mathrm{l}$ water and 80 fishes

\begin{tabular}{|c|c|c|}
\hline $\mathrm{Aq}$ & $\begin{array}{l}\text { Fishes in } \\
200 \text { l aquaria }\end{array}$ & $\begin{array}{l}\text { Infection method ( } 24 \mathrm{~h} \text { expo- } \\
\text { sure) with small }(10 \mathrm{l}) \text { aquarid } \\
\text { each containing } 20 \mathrm{fish}\end{array}$ \\
\hline 1 & $\begin{array}{l}40 \text { rainbow trout and } \\
40 \text { brown trout }\end{array}$ & $\begin{array}{l}4 \text { aquaria each with } 150-200 \\
\text { parasites ( } 2 \text { for rainbow trout } \\
\text { and } 2 \text { for brown trout) }\end{array}$ \\
\hline 2 & $\begin{array}{l}40 \text { rainbow trout and } \\
40 \text { Atlantic salmon } \\
\text { (Scottish, Conon) }\end{array}$ & $\begin{array}{l}4 \text { aquaria each with } 80-100 \\
\text { parasites ( } 2 \text { for rainbow trout } \\
\text { and } 2 \text { for Atlantic salmon) }\end{array}$ \\
\hline 3 & $\begin{array}{l}40 \text { rainbow trout and } \\
40 \text { Baltic salmon } \\
\text { (Finnish, Iljoki) }\end{array}$ & $\begin{array}{l}4 \text { aquaria each with } 80-100 \\
\text { parasites ( } 2 \text { for rainbow trout } \\
\text { and } 2 \text { for Baltic salmon) }\end{array}$ \\
\hline
\end{tabular}


and incubated for $17 \mathrm{~h}$ in humid chambers at room temperature, after which plates were pressed, dried, stained with methyl violet and lugol and destained in ethanol. The maximum width of the lysed zone perpendicular to the middle of the tail fin (fork) was then measured (0.1 $\mathrm{mm}$ accuracy). The lysed zone was expressed as percent of the lysed zone of reference rainbow trout fins on the same agarose plate (see Table 2).

Mucous cell count. In order to elucidate species differences in mucous cell density (independently of infection) and importance for the initial susceptibility to infection these cells were enumerated as follows. Tail fins from 10 uninfected fishes from the same batches as were used for the infection experiments were fixed in $4 \%$ phosphate-buffered formaldehyde for $7 \mathrm{~d}$, washed in distilled water, stained with Alcian Blue $(1 \%)$ in $3 \%$ acetic acid, rinsed in distilled water and finally mounted in Aquamount. The number of superficial mucous cells per area unit in the epithelium was then determined using a compound microscope (magnification 200x). In order to locate regional differences in cell density 5 adjacent zones (1 to 5 ) located from the axial fin edge (fork) to the tail peduncle, each covering $0.61 \mathrm{~mm}^{2}$, were counted in each fish.

Data processing and statistical procedures. The infection level was expressed as prevalence (percentage of fish infected), abundance (number of parasites per fish infected and uninfected) and intensity (number of parasites per infected fish) according to Margolis et al. (1982). Variance to mean ratio was calculated. The site selection of monogeneans was expressed as percentage of the parasite population registered in a particular site. Differences between means of samples were tested using a Student's t-test (level of significance was 0.05).

\section{RESULTS}

\section{Population dynamics of Gyrodactylus derjavini on various salmonid hosts}

The infection procedure was reproducible as judged from the uniform rainbow trout acceptance of parasites following the six $24 \mathrm{~h}$ exposures in small aquaria of this host. Gyrodactylus derjavini populations on rainbow trout increased in all three $200 \mathrm{l}$ aquaria to high levels within 3 to $4 \mathrm{wk}$ post-infection followed by a slight population decline. Brown trout experienced a marked increase of the parasite burden, which, however, peaked at a significantly lower level. Only a slight parasite population increase on both Baltic and Atlantic salmon was recorded (Fig. 2). It is noteworthy that almost all fishes initially became infected during the

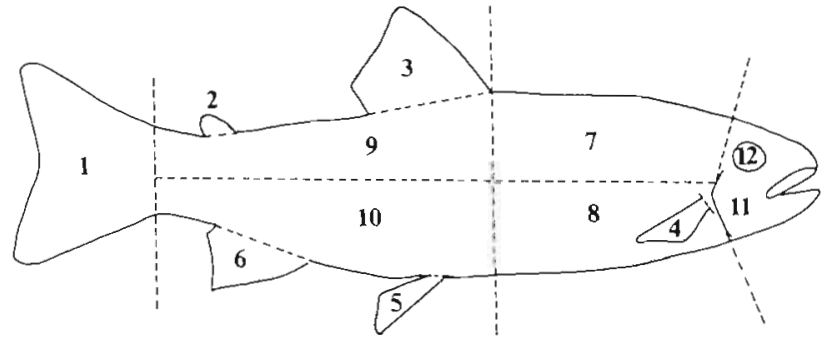

Fig. 1. Body parts on which the number of monogeneans were registered. 1- caudal fin, 2: adipose fin, 3: dorsal fin, 4: pectoral fin, 5: pelvic fin, 6: anal fin, 7 anterior dorsal body, 8: anterior ventral body, 9: posterior dorsal body, 10: posterior ventral body, 11. head, 12 : corned

infection procedure (no significant difference in abundance and prevalence in Week 1) but only the rainbow trout sustained a $100 \%$ infection in the following weeks. The variance to mean ration was highest in the rainbow trout groups in all experiments. However, no easily interpretable variation of this parameter was deduced in any group, although the elevated variance to mean ratio in the last weeks of the period indicates that the fish groups contained fish with very different abilities to combat the infection. Some mortality was recorded in all groups, especially $3 \mathrm{wk}$ after the initial infection (Fig. 2). In all these comparisons rainbow trout and the other salmonid group to be tested were kept together in the same aquarium providing a comparable infection pressure.

\section{Site specificity}

The initial infection of the salmonids was predominantly located on pectoral, tail, pelvic and anal fins. However, during the population increase the tail fin in rainbow trout, brown trout and Atlantic salmon became increasingly more heavily infected and harboured the larger proportion of the parasites. Further, in Baltic salmon the tail fin was the most frequently selected site during the first 3 wk but in the last weeks of infection the corneal surface was the primary choice of the gyrodactylids. The cornea was also an important microhabitat in the other salmonids for the monogeneans in the later weeks. In addition, the hind part of the body proper and the head in all salmonids tested became increasingly more heavily infected in that period (Fig. 3)

\section{Lysozyme activity in fins}

A marked lysozyme activity in the fish fins appearing as clear zones surrounding the fins in the Micrococcus 


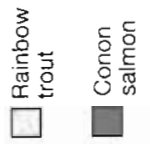

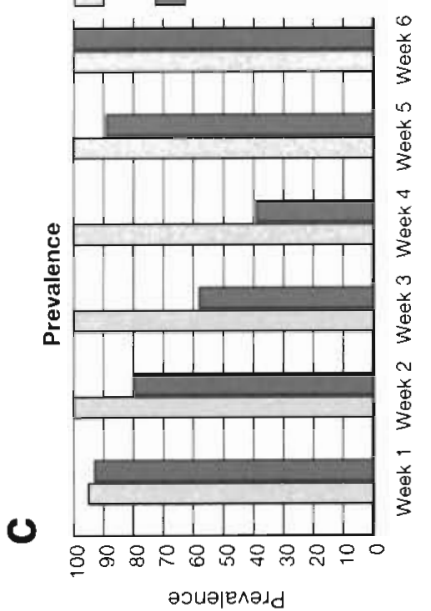

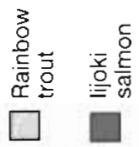

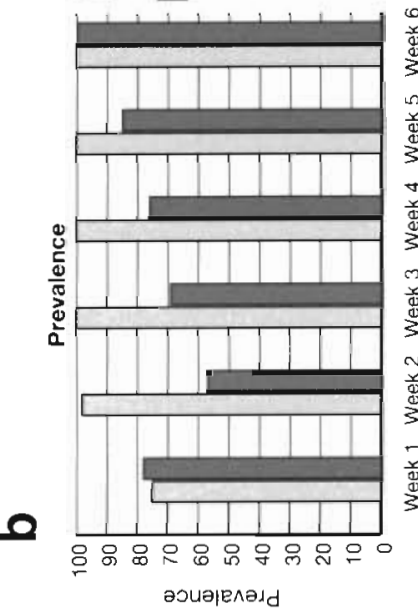

产亮

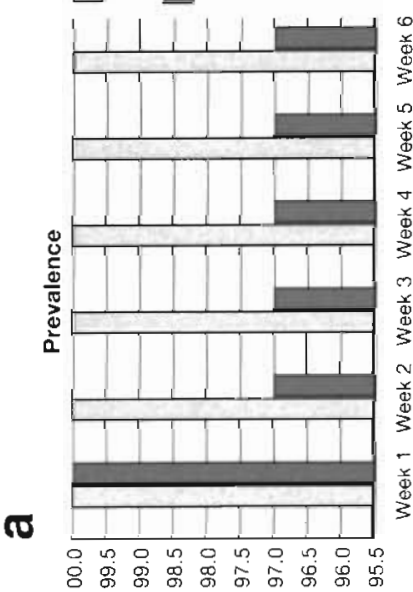
әэuอ|enadd

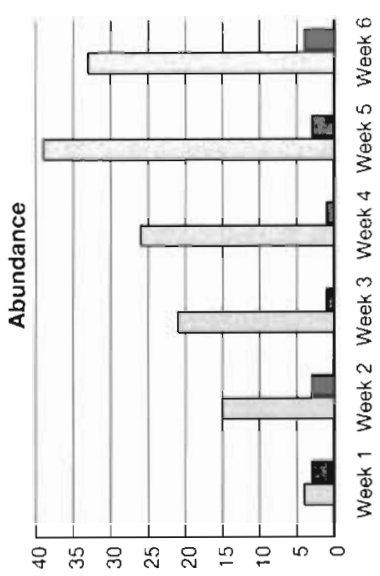

eouepung $\forall$
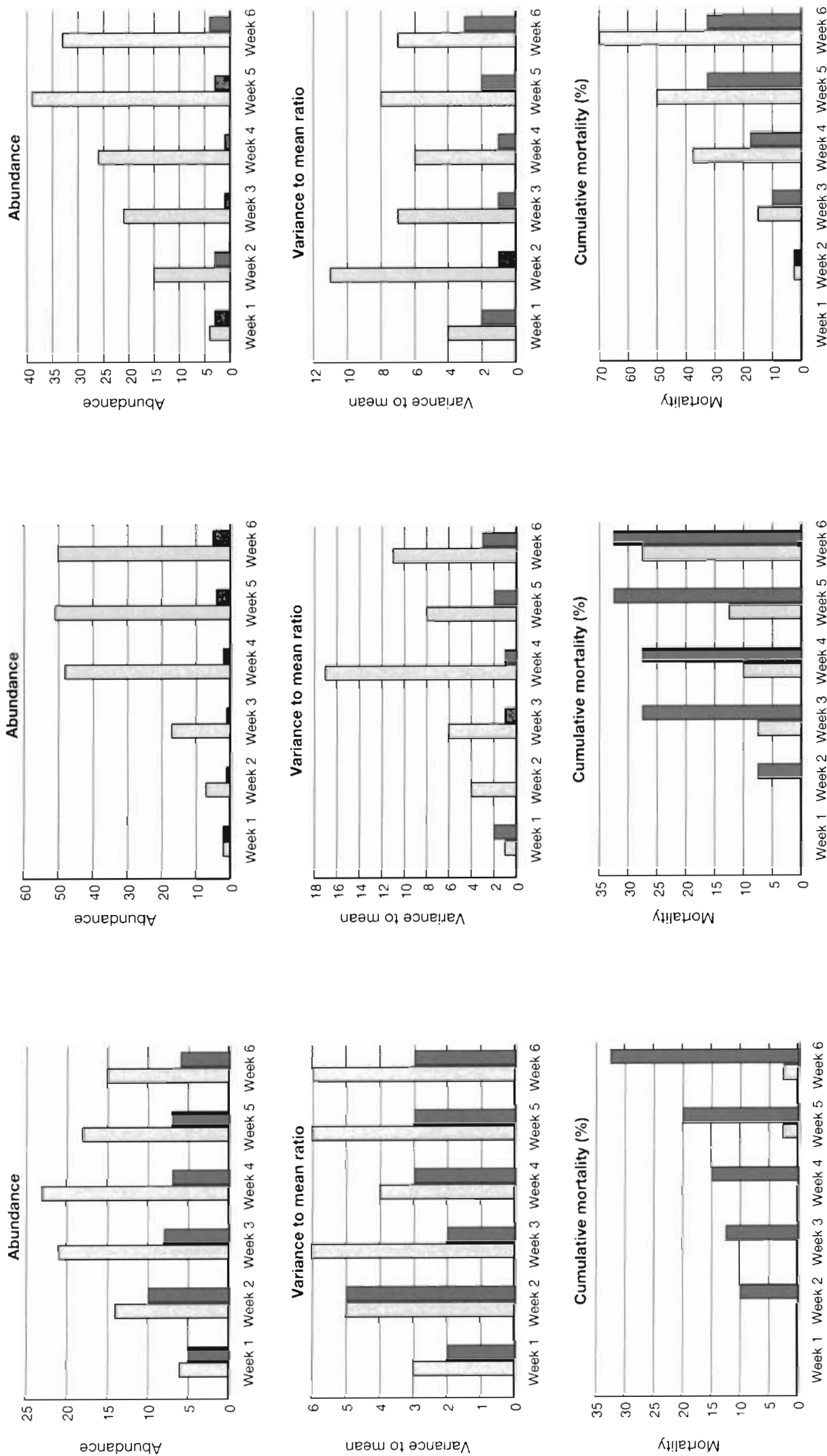

บยวน 의 ววนеนе

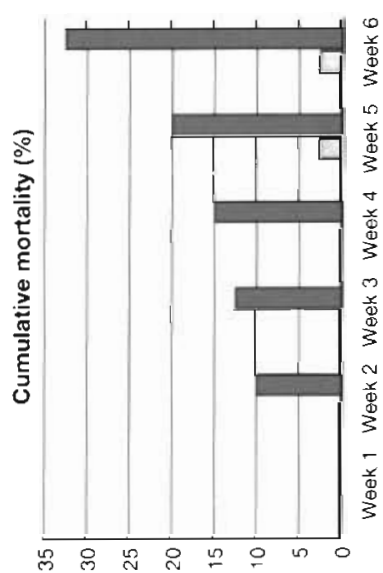

Á!̣eนOW
范考

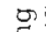

t

음

蛋

in

$\forall$ ్ㅡ

$\Xi$

ह

政

这

30

范

\%

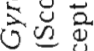

동

로

要

可

$\stackrel{g}{\Xi}$

跣

잉응

글

0

드음

으음

这蓠

万:

E्ष

욜

远

品

$>$ ह

过

을

马ิ

过

Фे

帘.

는

을

这

동

पु

$\Xi$

응

总

نㅇ

‥

诖正 
Table 2. Lysozyme activity in tail fins from 4 salmonids

\begin{tabular}{|lcc|}
\hline Fish & $\begin{array}{c}\text { No. of } \\
\text { fins }\end{array}$ & $\begin{array}{c}\text { Lysozyme activity (lysed } \\
\text { zone): percent of rainbow } \\
\text { trout activity }\end{array}$ \\
\hline Rainbow trout & 30 & 100 \\
Brown trout & 10 & 55.0 \\
$\begin{array}{l}\text { Baltic salmon } \\
\text { (Finnish, lijoki) }\end{array}$ & 10 & 70.0 \\
$\begin{array}{l}\text { Atlantic salmon } \\
\text { (Scottish, Conon) }\end{array}$ & 10 & 57.1 \\
\hline
\end{tabular}

lysodeicticus agarose gels was demonstrated. However, the activity was not correlated to the parasite susceptibility in rainbow trout and the other salmonids. Thus, rainbow trout fins exhibited in all cases a much stronger lysozyme activity (Table 2).

\section{Mucous cells in tail fins}

The number of superficial mucous cells per $0.61 \mathrm{~mm}^{2}$ varied significantly in the different fin zones of a single fish species. Thus, the edge of the fins (zone 1) exhibited in all cases a lower number of cells. Among host species the rainbow trout tail fins had a lower cell density than the brown trout tail fins, which in turn scored lower than the 2 salmon strains (Table 3 ).

\section{DISCUSSION}

The decisive factors of the host specificity found in most monogenean-fish host systems are still insufficiently elucidated. However, the present study may provide some clues for further efforts to explain this fundamental aspect of monogenean biology. Basically, this work has clearly documented that various salmonid hosts exhibit highly differing degrees of suscep- tibility to the Danish strain of Gyrodactylus derjavini tested. Rainbow trout was clearly the most susceptible species and brown trout a more resistant species. Baltic and Atlantic salmon both showed low susceptibility to the parasite although both strains were able to support a minor population. This gyrodactylid has previously been reported from rainbow trout (Buchmann et al. 1995, Shinn et al. 1995), from brown trout (Ergens 1983, Malmberg \& Malmberg 1993, Shinn et al. 1995) and from Atlantic salmon (Malmberg \& Malmberg 1993, Mo 1993, Shinn et al. 1995). Under natural conditions all these species and strains are able to sustain a population of this parasite although at different levels. It has previously been indicated that a genetic factor is involved in the differences of host susceptibility to infection with a Gyrodactylus species (Madhavi \& Anderson 1985, Bakke et al. 1990, Bakke \& MacKenzie 1993) and it is evident that both the genes of the parasite (virulence) and the genes of the host (resistance factors) are important. In support of this, the susceptibility of salmonids to infection with a Norwegian strain of $G$. salaris was previously found to differ significantly: A Norwegian and a Baltic stock of the Atlantic salmon exhibited totally different susceptibilities (Bakke et al. 1990); the Scottish Conon stock showed low resistance (Bakke \& Mackenzie 1993); the brown trout showed a poor ability to sustain a $G$. salaris population (Jansen \& Bakke 1995); and the rainbow trout individuals varied considerably in susceptibility to infection but sustained as a population significant parasite numbers (Bakke et al. 1991).

In our study an isolated strain of Gyrodactylus derjavini from a single trout farm in Denmark was multiplicated in the laboratory and used as the infection source in standardized procedures for infection of the various salmonids. Therefore, different strains of parasites are unlikely to explain the recorded differences. Macroenvironmental factors may influence the performance of gyrodactylids (Malmberg 1993). However, in the present study these parameters were kept constant, and in all fish tanks rainbow trout were kept as

Table 3. Mucous cell density (no. of cells per $0.61 \mathrm{~mm}^{2}$ ) (mean and SD) in tail fins from 4 salmonids. Tail fins were divided into zones 1 to 5 from edge to tail peduncle. A total of 10 fins were counted in each group. "Significantly higher than rainbow trout; " significantly higher than brown trout

\begin{tabular}{|c|c|c|c|c|c|}
\hline Salmonid & Zone 1 & Zone 2 & Zone 3 & Zone 4 & Zone 5 \\
\hline Rainbow trout & $23.9(10.5)$ & $70.1(14.9)$ & $89.0(15.9)$ & $101.6(18.6)$ & $115.7(29.6)$ \\
\hline Brown trout & $70.5(28.3)^{\circ}$ & $124.3(41.1)^{\circ}$ & $128.1(33.8)^{\circ}$ & $140.4(36.9)^{\circ}$ & $144.0(45.6)^{\circ}$ \\
\hline $\begin{array}{l}\text { Baltic salmon } \\
\text { (Finnish, Iijoki) }\end{array}$ & $102.6(34.6)^{\cdots}$ & $209.9(44.4)^{\cdots}$ & $241.1(88.9)^{\cdots}$ & $276.7(116.9)^{*}$ & $283.0(137.6)^{\cdots}$ \\
\hline $\begin{array}{l}\text { Atlantic salmon } \\
\text { (Scottish, Conon) }\end{array}$ & $152.5(32.4)^{*}$ & $227.0(31.3)^{\cdots}$ & $220.0(35.8)^{\cdots}$ & $272.8(65.5)^{\cdots}$ & $276.6(60.1)^{\cdots}$ \\
\hline
\end{tabular}



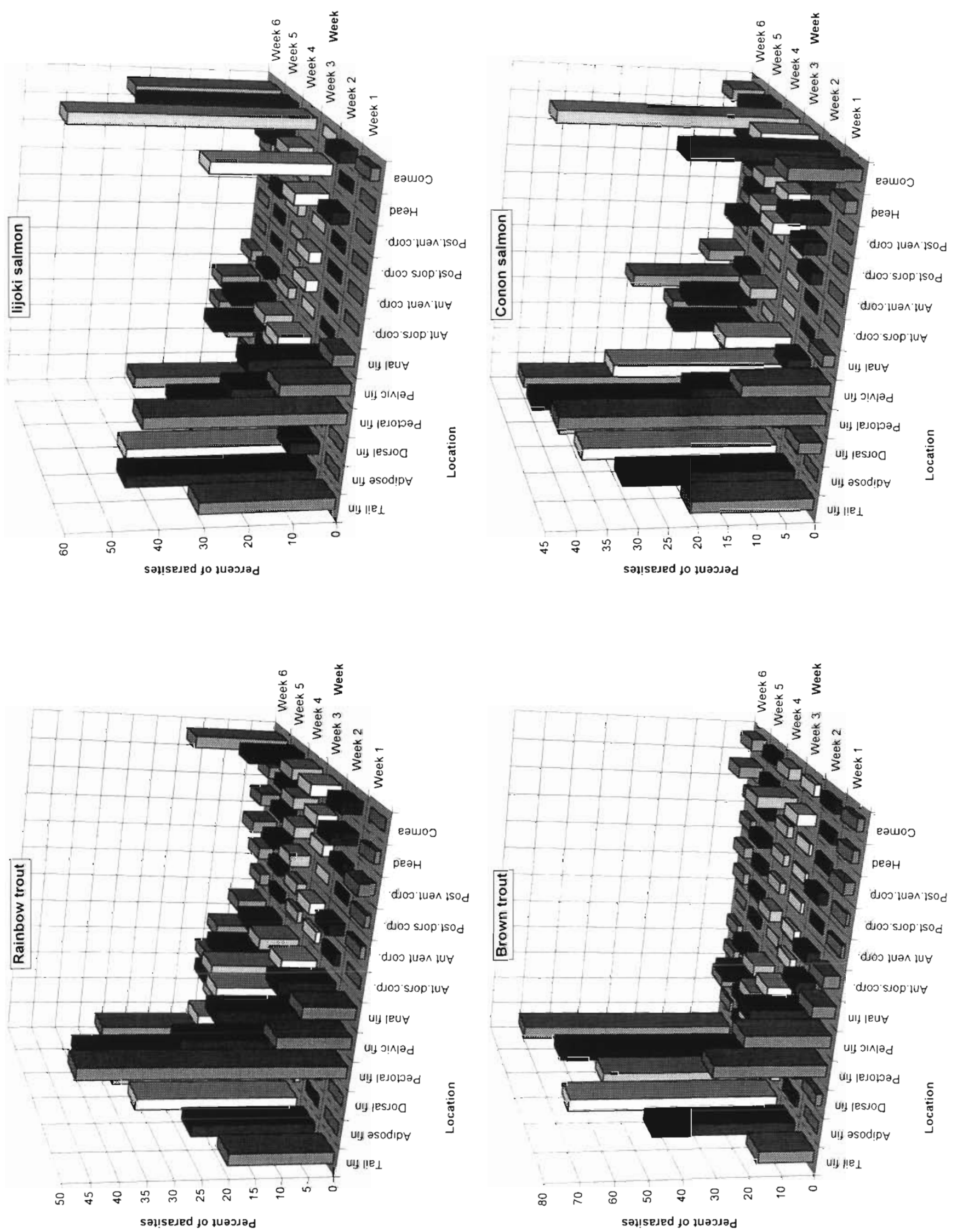
reference and received equal infection pressure throughout the experiments. Therefore, the experimental results should be explained by differences in the hosts susceptibilities, which probably result from a large variety of factors. One possibility is that different hosts differ with respect to the chemical composition of the superficial epidermis and mucus (Harris et al. 1973) or chemical communication substances (Hara 1993) and that monogeneans with a well-developed sensory and nerve system (Lyons 1969, Reuter 1987) are attracted by certain favourite hosts. Indeed, specific blood antigens in fish mucus could be part of this process (O'Rourke 1961).

We found that the initial attachment of parasites (Week 1) did not differ significantly between rainbow trout, brown trout and the tested strains of salmon. The different degrees of susceptibility became evident only in the following weeks. This suggests that these different salmonid hosts emit a gyrodactylid attractant to the same extent and that additional factors in the host epidermis are responsible for the varying degrees of resistance. A number of factors can be suggested which may account for this. The anatomy of the host epidermis could differ among salmonid species and provide microhabitats better suited for certain parasites than for others. The well-documented non-specific defence mechanisms (Fletcher 1982) and specific immune response of the fish host (St. Louis-Cormier et al. 1984) could also influence resistance to monogenean invasion. Thus, a number of active non-specific substances such as proteases (Hjelmeland et al. 1983), trypsin (Braun et al. 1990), lysozyme (Lie et al. 1989) and specific antibodies (Fletcher \& Grant 1969, Bradshaw et al. 1971, Lobb \& Clem 1981, St. Louis-Cormier et al. 1984) have been detected in fish mucus. As both the resistance of brown trout to ectoparasite invasion and the epidermis change seasonally (Pickering 1977, Pickering \& Christie 1980) and the composition of fish mucus varies during a Gyrodactylus sp. infection (Moore et al. 1994), the epidermal surface should be a relevant subject for study in this context. Actually, the present study demonstrated that salmonids with high mucous cell density on the fins showed the highest resistance to infection with $G$. derjavini, suggesting that the mucous cells affect this parameter. The Scottish salmon tested in Norway did not show the same degree of susceptibility to $G$. salaris infection (Bakke et al. 1992b, Bakke \& MacKenzie 1993) as we found to $G$. derjavini, which suggests that a more complex explanation is needed. However, these authors did not record the density of mucous cells in their experimental hosts. When rainbow trout were infected with $G$. colemanensis, a decrease in the mucous cell density throughout the infection period was seen (Wells \& Cone 1990), suggesting an exhaustion of the epidermis during infection. That lysozyme production of fishes plays a role in resisting monogenean invasion has been suggested by Vladimirov (1971). However, the lysozyme activity of fins from salmonids in this experiment was not positively correlated with resistance to $G$. derjavini infection, as we found the most susceptible species (rainbow trout) to possess the strongest lysozyme activity in the fins.

The Gyrodactylus derjavini population variation expressed in both rainbow trout and brown trout experimental groups followed the typical pattern previously seen in other fish host/Gyrodactylus spp. systems. The initial multiplication of the ectoparasites to a peak followed by a more or less strong decline is known from Gyrodactylus alexanderi on Gasterosteus aculeatus (Lester \& Adams 1974), from G. bullatarudis on Poecilia reticulata (Scott 1985), G. colemanensis and $G$. salmonis on Oncorhynchus mykiss (Cusack 1986. Cone \& Cusack 1988), and G. salaris on Salmo salar (Bakke et al. 1990, Bakke \& Mackenzie 1993) and on Salvelinus fontinalis (Bakke et al. 1992a). A clear-cut explanation for this variation has not yet been provided but may include a range of immunological processes and parameters. Likewise, the characteristic microhabitat selection of $G$. derjavini on the 4 salmonids tested is not readily explained. The initial invasion of pectoral fins, pelvic fins and anal fins could be explained by the infection method, as these parts of the fish make first contact with the parasites on the aquarium bottom. The subsequent transfer of $G$. derjavini to the tail fin involves an active movement of parasites and corresponds to the behaviour of $G$. colemanensis on rainbow trout (Cone \& Cusack 1989). It differs markedly from the site selection of G. salaris on Salmo salar, where the dorsal fin and pectoral fins are preferred (Jensen \& Johnsen 1992). Normally G. salaris is not recovered from the gills, but recently this organ was also shown under some circumstances to be vulnerable to infection with $G$. salaris (Appleby \& Mo 1997). G. turnbulli on $P$. reticulata also showed a dynamic migration posteriorly after a random initial infection (Harris 1988). Improved feeding and dispersal capacity result from this behaviour, which during evolution could have been encoded into the parasite genome. However, in other non-gyrodactylid monogeneans the specialized microhabitat selection can be a strategy for optimization of intraspecific contactfacilitating mating (Rohde 1977, Buchmann 1989). The change of parasite distribution on the host during the phase of population increase could be explained by a crowding effect triggering the migration of parasites to new foraging sites. Alternatively, the recorded change of habitat during the population decrease could also be explained by the parasites' escape from localized epithelial immune reactions or pathologically changed 
structures, a mechanism which also was indicated by Paperna et al. (1984) in the Benedenia monticelli/liza spp. association. Thus, following a heavy infection with $G$. derjavini on the tail fin of rainbow trout, the total parasite population on the host declines concomitant with an increase of the subpopulation on the corneal surface on the fish. Likewise, Baltic salmon in particular experienced a marked colonization of parasites on the cornea in the final period. Although the cornea normally is an unsuitable and exposed microhabitat for the parasite, this simple anatomical structure without mucous cells, lymphocytes and macrophages (Hibiya 1982) may serve as a refugium with a reduced immune reaction towards the ectoparasites during this phase.

The present findings about host susceptibility may have some practical application, as restocking of Danish waters with Salmo trutta and Salmo salar (both the Iijoki and the Conon stock) is in progress and raises questions about parasite contamination from rainbow trout farms. Thus, it appears that, where Gyrodactylus derjavini is concerned, the salmon restocking programme is not threatened and the brown trout seems able to cope with infections with this organism.

Gyrodactylus derjavini is probably an endemic species in native brown trout in Denmark, which could explain the relative resistance of this host to that particular organism. Rainbow trout, in contrast, were introduced in the late 1880 s and did not develop an innate resistance to infection with this gyrodactylid during evolution. The decrease in parasite counts in the later stages of infection in rainbow trout and the migration of parasites to the cornea suggest, nonetheless, that this host is capable of mounting an immune response during infection.

Acknowledgements. This work was supported by the Danish Research Councils and is part of the programme on 'Disease prevention, genetics and nutrition in rainbow trout production'

\section{LITERATURE CITED}

Appleby C, Mo TA (1997) Population dynamics of Gyrodactylus salaris (Monogenea) infecting Atlantic salmon parr Salmo salar, in the river Batnfjordselva, Norway. J Parasitol (in press)

Bakke TA (1991) A review of the inter-and intraspecific variability in salmonid hosts to laboratory infections with Gyrodactylus salaris Malmberg. Aquaculture 98:303-310

Bakke TA, Harris PD, Jansen PA (1992a) The susceptibility of Salvelinus fontinalis (Mitchill) to Gyrodactylus salaris Malmberg (Platyhelminthes; Monogenea) under experimental conditions. J Fish Biol 41:499-507

Bakke TA, Harris PD, Jansen PA, Hansen LP (1992b) Host specificity and dispersal strategy in gyrodactylid monogeneans, with particular reference to Gyrodactylus salaris (Platyhelminthes, Monogenea). Dis Aquat Org 13:63-74
Bakke TA, Jansen PA, Hansen LP (1990) Difference in the host resistance of Atlantic salmon, Salmo salar L, to the monogenean Gyrodactylus salaris Malmberg, 1957. J Fish Biol 37:577-587

Bakke TA, Jansen PA, Kennedy CR (1991) The host specificity of Gyrodactylus salaris Malmberg (Platyhelminthes, Monogenea): susceptibility of Oncorhynchus mykiss (Walbaum) under experimental conditions. J Fish Biol 39: $45-57$

Bakke TA, Mackenzie K (1993) Comparative susceptibility of native Scottish and Norwegian stocks of Atlantic salmon, Salmo salar L., to Gyrodactylus salaris Malmberg: laboratory experiments. Fish Res 17:69-85

Bradshaw CM, Richard AS, Sigel MM (1971) IgM antibodies in fish mucus. Proc Soc Exp Biol Med 136:1122-1124

Braun R, Arnesen JA, Rinne A, Hjelmeland K (1990) Immunohistological localization of trypsin in mucus-secreting cell layers of Atlantic salmon, Salmo salar L. J Fish Dis 13 233-238

Buchmann K (1989) Microhabitats of monogenean gill parasites on European eel (Anguilla anguilla). Folia Parasitol $36: 321-329$

Buchmann K (1993) A note on the humoral immune response of infected Anguilla anguilla against the gill monogenean Pseudodactylogyrus bini. Fish \& Shellfish Immunol 3: 397-399

Buchmann K, Bresciani J (1997) Parasitic infections in pond reared rainbow trout (Oncorbynchus mykiss) in Denmark Dis Aquat Org 28:125-138

Buchmann K, Uldal A, Lyholt HCK (1995) Parasite infections in Danish trout farms. Acta Vet Scand 36:283-298

Bychowsky BE (1957) Monogenetic trematodes, their systematics and phylogeny. Academy of Sciences USSR Moscow. (English translation of the American Institute of Biological Sciences, 1961)

Cone DK, Cusack R (1988) A study of Gyrodactylus colemanensis Mizelle and Kritsky, 1967 and Gyrodactylus salmonis (Yin and Sproston, 1948) (Monogenea) parasitizing captive salmonids in Nova Scotia. Can J Zool 66:409-415

Cone DK, Cusack R (1989) Infrapopulation dispersal of Gyrodactylus colemanensis (Monogenea) on fry of Salmo gairdneri. J Parasitol 75:702-706

Cusack R (1986) Development of infections of Gyrodactylus colemanensis Mizelle and Kritsky, 1967 (Monogenea) and the effect on try of Salmo gairdneri Richardson. J Parasitol $72: 663-668$

Ergens R (1983) Gyrodactylus from Eurasian freshwater Salmonidae and Thymallidae. Folia Parasitol 30:15-26

Fletcher TC (1982) Non-specific defence mechanisms of fish. Dev Comp Immunol 2:123-132

Fletcher TC, Grant PT (1969) Immunoglobulins in the serum and mucus of the plaice (Pleuronectes platessa). Biochem J 115:65

Hara TJ (1993) Chemoreception. In: Evans DH (ed) The physiology of fishes. CRC Press, Boca Raton, p 191-218

Harris JE. Watson A, Hunt S (1973) Histochemical analysis of mucous cells in the epidermis of brown trout Salmo trutta L. J Fish Biol 5:345-351

Harris PD (1988) Changes in the site specificity of Gyrodactylus turnbulli Harris, 1986 (Monogenea) during infections of individual guppies (Poecilia reticulata Peters, 1859). Can J Zool 66:2854-2857

Hibiya $T$ (1982) An atlas of fish histology. Kodansha Ltd, Tokyo

Hjelmeland K, Christie M, Raa J (1983) Skin mucus protease from rainbow trout, Salmo gairdneri Richardson, and its biological significance. J Fish Biol 23:13-22 
Jahn TL, Kuhn LR (1932) The life history of Epibdella melleni Maccallum 1927, a monogenetic trematode parasitic on marine fishes. Biol Bull (Woods Hole) 62:89-111

Jansen PA, Bakke TA (1995) Susceptibility of brown trout to Gyrodactylus salaris (Monogena) under experimental conditions. J Fish Biol 46:415-422

Jensen AJ, Johnsen BO (1992) Site specificity of Gyrodactylus salaris Malmberg, 1957 (Monogenea) on Atlantic salmon (Salmo salar L.) in the River Lakselva, northern Norway. Can J Zool 70:264-267

Kearn GC (1976) Body surfaces of fishes. In: Kennedy CR (ed) Ecological aspects of parasitology. North-Holland Publishing Company, Amsterdam, p 185-208

Kearn GC (1994) Evolutionary expansion of the monogenea. Int J Parasitol 24:1227-1271

Lester RJG, Adams JR (1974) A simple model of a Gyrodactylus population. Int J Parasitol 4:497-506

Lie Ø, Evensen $\varnothing$, Sørensen A, Frøysadal E (1989) Study on lysozyme activity in some fish species. Dis Aquat Org 6: $1-5$

Lie $\varnothing$, Syed M, Solbu H (1986) Improved agar plate assays of bovine lysozyme and haemolytic complement activity. Acta Vet Scand 27:23-32

Lobb CJ, Clem W (1981) The metabolic relationship of the immunoglobulins in fish serum, cutaneous mucus, and bile. J Immunol 127:1525-1529

Lyons KM (1969) Compound sensilla in monogenean skin parasites. Parasitology 59:625-636

Madhavi R, Anderson RM (1985) Variability in the susceptibility of the fish host, Poecilia reticulata, to infection with Gyrodactylus bullatarudis (Monogenea). Parasitology 91:531-544

Malmberg G (1993) Gyrodactylidae and gyrodactylosis of salmonidae. Bull Fr Pêche Piscic 328:5-46

Malmberg G, Malmberg $M$ (1993) Species of Gyrodactylus (Platyhelminthes, Monogenea) on salmonids in Sweden. Fish Res 17:59-68

Margolis L, Esch GW, Holmes JC, Kuris AM, Schad GA (1982) The use of ecological terms in parasitology. J Parasitol 68:131-133

Mo TA (1993) Seasonal variations of the opisthaptoral hard parts of Gyrodactylus derjavini Mikailov, 1975 (Monogenea: Gyrodactylidae) on brown trout Salmo trutta L. parr and Atlantic salmon S. salar L. parr in the River Sand-

Responsible Subject Editor: W. Körting, Hannover, Germany vikselva, Norway. Syst Parasitol 26:225-231

Moore MM, Kaattari SL, Olson RE (1994) Biologically active factors against the monogenetic trematode Gyrodactylus stellatus in the serum and mucus of infected juvenile English soles. J Aquat Anim. Health 6:93-100

Nigrelli RF, Breder CM (1934) The susceptibility and immunity of certain fishes to Epibdella melleni, a monogenetic trematode. J Parasitol 20:259-269

O'Rourke FJ (1961) Presence of blood antigens in fish mucus and its possible parasitological significance. Nature 189: 943

Paperna I, Diamant A, Overstreet RM (1984) Monogenean infestations and mortality in wild and cultured Red Sea fishes. Helgoländer Meeresunters 37:445-462

Pickering AD (1977) Seasonal changes in the epidermis of the brown trout Salmo trutta (L.). J Fish Biol 10:561-566

Pickering AD, Christie P (1980) Sexual differences in the incidence and severity of ectoparasitic infestations of the brown trout, Salmo trutta L. J Fish Biol 16:669-683

Reuter M (1987) Immunocytochemical demonstration of serotonin and neuropeptides in the nervous system of Gyrodactylus salaris (Monogenea). Acta Zool 68:187-193

Rohde K (1977) A non-competitive mechanism responsible for restricting niches. Zool Anz 3/4:164-172

Scott ME (1985) Experimental epidemiology of Gyrodactylus bullatarudis (Monogenea) on guppies (Poecilia reticulata): short- and long-term studies. In: Rollinson D, Anderson RM (eds) Ecology and genetics of host-parasite interactions. Academic Press, New York, p 21-38

Shinn AP, Sommerville C, Gibson DI (1995) Distribution and characterization of species of Gyrodactylus Nordmann, 1832 (Monogenea) parasitizing salmonids in the UK, and their discrimination from G. salaris Malmberg, 1957. J Nat Hist 29:1383-1402

St. Louis-Cormier EA, Osterland CK, Anderson PD (1984) Evidence for a cutaneous secretory immune system in rainbow trout (Salmo gairdneri). Dev Comp Immunol 8:71-80

Vladimirov VL (1971) The immunity of fishes in the case of dactylogyrosis. Parasitologiya 5:51-58 (in Russian). English translation: Parasitology, Riverdale 1971, 1:58-68

Wells PR, Cone DK (1990) Experimental studies on the effect of Gyrodactylus colemanensis and G. salmonis (Monogenea) on density of mucous cells in the epidermis of fry of Oncorhynchus mykiss. J Fish Biol 37:599-603

Manuscript first received: October 23, 1996

Revised version accepted: December 9, 1996 